\section{MANCHESTER 1824}

The University of Manchester Brooks World Poverty Institute
A decade of poverty reduction in Kazakhstan 2000-2009: growth and/or redistribution?

\author{
Alma Kudebayeva ${ }^{1}$ \\ Armando Barrientos ${ }^{2}$
}

1, 2 Brooks World Poverty Institute, University of Manchester, UK

\section{Email: ${ }^{1}$}

alma.kudebareva@postgrad.manchest er.ac.uk

Email: $^{2}$

arrmando.barrientos@manchester.ac. uk
October 2013

BWPI Working Paper 187

Creating and sharing knowledge to help end poverty 


\begin{abstract}
This paper examines the main factors behind the strong decline in poverty experienced in Kazakhstan. Specifically, it examines the contribution of growth and redistribution to household consumption and to poverty indicators in Kazakhstan for the period 20012009. The analysis relies on estimates of pro-poor growth indices using cross-sections of household data. It finds that growth has been strongly pro-poor. Growth was the main driver behind the fall in poverty in the first half of the decade, but redistribution becomes important in sustaining poverty reduction in the latter part of the decade. Redistribution was crucial to sustaining poverty reduction in the aftermath of the financial crisis.
\end{abstract}

Keywords: Kazakhstan, poverty, growth, redistribution

Alma Kudebayeva is a PhD candidate at the Brooks World Poverty Institute, University of Manchester, UK.

Armando Barrientos is Research Director, Brooks World Poverty Institute, University of Manchester, UK.

\title{
Acknowledgements
}

Alma Kudebayeva gratefully acknowledges support from the Vienna Institute for International Economic Studies (WIIW) Global Development Network (GDN) Southeast Europe - Research Competition 2011/2012. 


\section{Introduction}

After the collapse of the Soviet Union, Kazakhstan transitioned from a planned economy to a market-oriented economy. Poverty became an important social issue in Kazakhstan during the transition period in the 1990s. With the dissolution of economic links with the other republics of the former Soviet Union, the economy experienced a deep recession, and as growth rates of real GDP decreased sharply, poverty rates climbed. Poverty trends reversed in the 2000s. Strong growth in the first years of the new century led to a decline in poverty headcount rates, which accelerated after 2005 . The decline in poverty was sustained through the financial crisis in 2007. What explains the rapid decline in poverty indicators in the 2000s? How was it sustained in the latter part of the decade? This paper addresses these two important questions using household survey data spanning the decade. It estimates pro-poor growth indexes, and it decomposes these estimates to measure the relative contribution of growth and distribution over time.

The factors explaining the onset of rapid economic growth in the new decade in Kazakhstan are well documented (Pomfret, 2005; Agrawal, 2008).Tight monetary policy applied by the National Bank of Kazakhstan reduced the inflation rate, while pension system reforms after 1998 shrank public sector debt. A rapid devaluation of the national currency in 1999 and a favourable rise in world prices for crude oil and wheat, the main exports, improved the balance of payments. Real GDP growth rates averaged 10 percent a year in the period 2000-2008, with increased oil production and prices as the main drivers. The Caspian oilfields experienced fast rising demand following the opening of the first independent pipeline through Russia in 2001 and the construction of a new pipeline from the oil-rich western part of Kazakhstan to China in 2010. Kazakhstan reaped the benefits from higher demand, higher prices and a strengthened position in the negotiation of transit fees (Pomfret, 2009).

The Global Financial Crisis began to affect Kazakhstan's economy in August 2007. Initially the main effects were felt in the financial and construction sectors. The banking sector had accumulated a large external foreign debt, amounting to 44 percent of GDP. By contrast, the external debt of the public sector amounted to only 2 percent of GDP in 2007. ${ }^{1}$ The financial crisis led to a substantial decline in lending from commercial banks to non-oil sectors of the economy, and the construction sector faced stagnation and bankruptcy. Due to favourable world prices for oil, the decline in growth of real GDP was not severe in 2007; nevertheless, growth rates declined sharply to 3.3 and 1.8 percent in 2008 and 2009 , respectively.

Trends in the poverty headcount rate reflected growth at the beginning of the decade and have continued to decline through to the end of the period. Redistribution through government antipoverty programmes may have helped sustain the declining trend in the

\footnotetext{
${ }^{1}$ The information is available from National Bank of Kazakhstan: http://www.nationalbank.kz/?docid=346
} 
poverty headcount rate, especially as growth faltered. Beginning in 2000 and through 2005, State Programmes ${ }^{2}$ targeted reductions in poverty. The 2000-2002 State Programme to Combat Poverty was followed by the 2003-2005 State Poverty Reduction Programme (UNDP Kazakhstan, 2008). The first programme focused on direct social support and employment; whereas the second focused on raising the levels of wages, minimum pensions and social assistance transfers. These two programmes absorbed approximately USD 4.55 billion in public expenditures, amounting to 2.3 percent of GDP annually for the period 2000-2005.

Beginning in 2007, and in response to the crisis, the Government of Kazakhstan began a stimulus package - the State Anti-Crisis Programme (ACP) - with funds from the National Fund of the Republic of Kazakhstan (NFRK). ${ }^{3}$ The package was aimed at stabilising consumption. A raft of family benefits was introduced. These included allowances for families with children whose per capita income was lower than the cost of a basic food basket. In addition, in 2009-2012 the wages of public sector employees and pensions benefits rose annually by 25 percent. Transfers from the NFRK to the state budget in support of various developmental and unemployment reduction programmes amounted to USD 2.13 billion in 2007, 8.94 billion in 2008 and 7.41billion in 2009 (Ministry of Finance of the Republic of Kazakhstan) ${ }^{4}$ In 2009, the combined stimulus package reached approximately 16 billion USD, or 15 percent of GDP in 2009 (Jandosov, Sabyrova and Mogilevsky, 2010). It is to be expected that the stimulus package will have generated significant redistribution, boosting general living standards, but it is an empirical question whether it had a more than proportionate impact on lowincome households.

Available research on the relationship between growth and poverty in Kazakhstan has relied on Household Budget Surveys (KHSB) data. Verme (2006) applies a range of methodologies to evaluate changes in income, poverty, and income distribution in 2001 and 2002. He finds that rapid GDP growth translated into a very modest growth in mean household income, while income poverty and inequality decreased significantly in the period. He concluded that growth was pro-poor. Esanov (2006) examines the period 2001-2004, and finds that declining inequality was the main driving force behind the

\footnotetext{
${ }^{2}$ The information is available from http://ru.government.kz/site/news/2012/06/24; http://adilet.minjust.kz/rus/docs/P030000296

${ }^{3}$ The National Fund of the Republic of Kazakhstan (NFRK), created in 2000, was established as a stabilisation fund to protect the economy from fluctuating prices for oil, gas and metals. The National Bank of the Republic of Kazakhstan monitors the assets of the National Fund. At the end of 2010 the assets of the NFRK amounted to USD 30.57 billion.

${ }^{4}$ Among these programmes, the following had a direct focus on poverty reduction: the State Development Programme for Rural Areas (2004-2010); the State Development Programme for Residential Construction (2005-2007 and 2008-2010); the State Programme for the Reform and Development of Healthcare (2005-2010); and the State Education Development Programme (2005-2010). Information on these programmes is available online from http://www.minfin.kz/index.php?uin=1120634837\&lang=rus $\quad$ and http://ru.government.kz/documents/govprog .
} 
significant reduction in poverty in the early part of the decade. Using a computable general equilibrium model, calibrated with National Income Accounts and KHBS data for 2001-2005, Hare and Naumov (2008) simulated the impact of an oil price shock on the economy. Their results show that an oil price shock is likely to be modestly pro-poor in terms of incomes, but the effects are reversed when the focus is on household consumption. This is because the poorest 10 percent of households draw most of their income from social benefits, while the wealthiest draw most of their income from labour earnings and profits. To our knowledge, there is no substantive research on the impact of the current crises on poverty and inequality.

Identifying the relative contribution of growth and redistribution to the sustained reduction shown by poverty rates in Kazakhstan in the 2000s is essential to assessing the sustainability of this trend. It can make a contribution to knowledge on the scope and limitations of commodity-based growth as a strategy for sustaining low poverty rates into the future. It will also throw light upon the effectiveness and sustainability of antipoverty policies and of the stabilisation policies in the latter part of the decade.

This paper is divided into four main sections. Section 2 introduces a measure of pro-poor growth to be used in the analysis below. Section 3 describes the data employed in the empirical analysis. Section 4 reports on the analysis of consumption growth and on estimates of measures of pro-poor growth for Kazakhstan. Section 5 examines changes in income sources for households in poverty to provide additional information on the relative significance of redistributive channels in Kazakhstan. A final section draws out the main conclusions.

\section{Measuring pro-poor growth}

The high and sustained rates of growth experienced by Kazakhstan are an important factor in the rapid reduction in poverty in the 2000s. The issue for this paper is to assess the relative contribution of economic growth and redistribution over the decade. Pro-poor growth has been defined as growth 'that enables the poor to actively participate in and significantly benefit from economic activity' (Kakwani and Pernia, 2000:3). Pro-poor growth measures aim to provide a summary estimate of the extent to which growth is poverty reducing.

At a basic level, growth is poverty reducing when the observed poverty elasticity of growth, the change in a poverty measure associated with a change of one percent in the rate of growth, is positive. However, a stricter measure of pro-poor growth helps to disentangle the distributional effects of growth. This is important for both theoretical and a policy reasons. To the extent that maximising growth does not necessarily entail the maximisation of poverty reduction, it becomes essential to develop pro-poor growth measures that could clarify the conditions under which maximal poverty reduction could be achieved. 
To this effect, this section introduces the growth incidence curve (GIC) developed by Ravallion and Chen (2003) and the poverty equivalent growth rate (PEGR) developed by Kakwani and Son (2008). The analysis in the following section estimates the GIC and the PEGR for Kazakhstan and decomposes the reduction in poverty experienced in the 2001-2009 decade into growth and distribution components.

To provide a direct visual description of rates of consumption growth across socioeconomic groups, the next section will show growth incidence curve (GIC). They plot the growth rate $g$ at time $t$ for each percentile $p$ of per capita expenditure $y$ as in:

$$
g_{t}(p)=\left[\frac{y_{t}(p)}{y_{t-1}(p)}\right]-1
$$

The PEGR (Kakwani and Son, 2008) focuses on a class of additively decomposable poverty functions of the type:

$$
\theta=\int_{0}^{z} P(z, x) f(x) d x
$$

Where $z$ is the poverty line, $x$ is a random variable with density $f(x)$ capturing individual welfare. The Foster-Greer-Thorbecke (FGT) (1984) poverty measure belongs to this class of additively decomposable poverty measures. It defines $P(z, x)=(z-x / z)^{\alpha}$ in (2), where $\alpha$ can be interpreted as capturing aversion to poverty. When $\alpha$ is set at 0,1 , or 2 , the poverty function in (2) delivers the poverty headcount rate, the poverty gap, and the poverty gap squared measures, respectively.

In the analysis below, we rely on the index proposed by Kakwani and Son (2008), the poverty equivalent growth rate, which can be written as:

$$
\text { PEGR }=\gamma^{*}=\left(\frac{\delta}{\eta}\right) \gamma=\varphi \gamma
$$

Where $y$ is actual rate of growth of mean income; $\delta$ is the percentage change in poverty associated with a one percent change in mean income in conditions where inequality remains unchanged. The PEGR can be defined as:

the growth rate in income $\gamma^{*}$ that would result in the same proportional change in poverty as the present growth rate $y$ if the growth process was not accompanied by any change in relative inequality (i.e. when everyone in society received the same proportional benefits of growth) (Kakwani and Son 2008: 647).

In (3) the observed rate of growth $\mathrm{y}$ is adjusted by $\varphi$, the ratio of the poverty elasticity of growth to the poverty elasticity of growth computed with inequality unchanged.

It is then possible to distinguish relative pro-poor growth from absolute pro-poor growth. Defining $\varphi=(\delta / \eta)$ and $\varphi^{*}=\left(\delta / \eta^{*}\right)$, its absolute growth equivalent, where: 
$\eta=\frac{1}{\theta} \int_{0}^{H} \frac{\partial P}{\partial x} x(p) d p$

Where $p$ is percentile, and:

$$
\eta^{*}=\frac{\mu}{\theta} \int_{0}^{H} \frac{\partial P}{\partial x} d p
$$

Growth is pro-poor in relative terms if $\varphi>1$, that is, if the growth rate of mean income is greater than the actual growth rate. It is pro-poor in absolute terms if $\varphi^{*}>1$. Kakwani and Son (2008) propose the poverty equivalent growth rate (PEGR) index, which satisfies monotonicity and takes account of the level of growth. Writing the PEGR as:

$$
\gamma^{*}=\gamma+(\varphi-1) \gamma
$$

and

$$
\gamma^{*}=\gamma\left[1+\left(\varphi-\varphi^{*}\right)\right]+\left(\varphi^{*}-1\right) \gamma
$$

can help to pinpoint the interpretation of the index. The PEGR measure satisfies the basic monotonicity condition, such that the reduction (increase) in poverty is a monotonically increasing (decreasing) function of the PEGR. It also takes account of the level of growth. Growth will be pro-poor in a relative sense if $\gamma^{\star}>\gamma$, which is satisfied if $\gamma>0$ and $\varphi>1$. Growth will be pro-poor in an absolute sense when $\gamma>0$ and $\varphi^{*}>1$ which is satisfied when $\gamma<0$ and $\varphi^{*}<1$. Pro-poor growth in the absolute sense entails relative pro-poor growth, but not the other way around.

\section{Data}

The analysis in the paper relies on data from the Kazakhstan Household Budget Survey (KHBS) from 2001 to 2009 provided by the Agency of Statistics of the Republic of Kazakhstan (ASRK).

The KHBS is a nationally representative annual household survey collecting information on 12,000 households. The survey sample is representative down to the oblast (province) level, and it is stratified according to rural and urban sectors, as well as by small, medium and large cities. The questionnaires contain four modules: (i) daily expenditures on food and necessities of households; (ii) quarterly expenditures for clothes, durables, utilities, education, healthcare, transportation, other expenditures and incomes of household members; (iii) housing conditions, livestock, equipment and machinery, education, and employment; and (iv) household composition and size. In 
2002, 2003 and 2005, two supplementary modules surveyed health and education variables for household members.

Here we focus on annual cross-section datasets extracted from the KHBS, ${ }^{5}$ but it is important to note a break in the survey methodology in 2006. Between 2001 and 2005, data from the full sample of households was collected quarterly. On paper, the sample was selected annually by the Statistics Agency. Beginning in 2006, the survey methodology changed to surveying 3,000 households each quarter, with the information consolidated into annual datasets for the 12,000 households. However, since 2009 the survey returned to the methodology used in 2001-2005, that is collecting data from the full sample every quarter. The survey also adopted a rotating sample, with 25 percent of households surveyed replaced every four quarters.

The analysis will focus on per capita consumption expenditure as the welfare indicator. Consumption expenditures are the main welfare indicator commonly employed in developing countries, with income featuring more prominently in studies of middleincome countries. For a transition economy like Kazakhstan, both consumption expenditures and income are appropriate to the measurement of poverty and inequality. In the paper the focus on consumption expenditure will better capture living standards among low-income groups. We focus on per capita consumption expenditures computed by dividing total household expenditures by household size. Some researchers make a strong case for using adult equivalent expenditures to take account of household economies of scale and the different 'costs' of children (Deaton and Muellbauer, 1986; Deaton and Paxson, 1998; Lanjouw and Ravallion, 1995). Having explored this issue with the data, we found only marginal differences in poverty estimates using per capita household expenditure and alternative OECD and WHO equivalence scales.

This analysis relies on official poverty lines calculated by the Agency of Statistics of the Republic of Kazakhstan. Poverty lines are set by tracking the value of a minimum subsistence consumption basket reflecting nutrition standards developed by the National Nutrition Institute. These nutrition standards also serve as the basis for cost of living calculations. Different baskets are constructed for the five regions, for nine age groups, and separately for females and males. This information is used to identify a mean national consumption basket. The cost of this consumption basket is calculated monthly, based on regional prices, separately for urban and rural areas. The costs of non-food goods and services are included as an adjustment to the food costs. Currently, non-food costs are estimated as an additional 40 percent of the food costs. From 2006, the Agency of Statistics applied a new methodology for the calculation of the subsistence

\footnotetext{
${ }^{5}$ In related work we have constructed a panel dataset for 2001-2009, with identification based on birth year, gender and first name of individuals in household. Tests of robustness, representativeness, and attrition bias for the panel dataset are encouraging. In total, 2580 households are present in all waves.
} 
minimums (SM) by expanding the range of goods included from 20 to 43 products, and setting a 2,175 Kcal per day as the nutrition standard. The adjustment for non-food costs was raised from 30 percent to 40 percent. To enable comparison across regions and across years, gross per capita real consumption expenditures were adjusted with official regional poverty lines.

\section{Was growth pro-poor In Kazakhstan?}

This section begins by presenting growth incidence curves for key years, and then discusses findings from the estimation of poverty equivalent growth rates and growth and distribution components. All estimates are based on cross-sectional data for 20012009.

\section{Growth incidence curves for Kazakhstan 2001-2009}

Growth incidence curves provide information on observed changes in welfare indicators for percentile groups over time. The shape of the line linking these observed changes gives a sense of the distribution of gains and losses. Figures $1 \mathrm{a}, 1 \mathrm{~b}$ and $1 \mathrm{c}$ show estimates of Kazakhstan's GIC for three periods, 2001-2005, 2006-2009 and 2001-2009, respectively. The period breaks divide the decade into two halves, but it also matches the changes in the survey methodology.

The GIC for 2001-2009 in Figure 1c illustrates the main finding that consumption growth was positive and stronger for groups in the lower percentiles of consumption in the initial year. At the bottom of the distribution of consumption, consumption grew by over 10 percent for the period, compared to just above 7 percent for the median and just above 4 percent for the groups with highest levels of consumption. The GICs lie above zero everywhere, establishing that first-order dominance is present, and suggesting that poverty has decreased for a broad class of poverty lines and poverty measures. Curves are strictly decreasing over higher quintiles, implying that inequality as measured by consumption has fallen over the period too. 
Figure 1. Growth incidence curves for Kazakhstan

(a) $2001-2005$

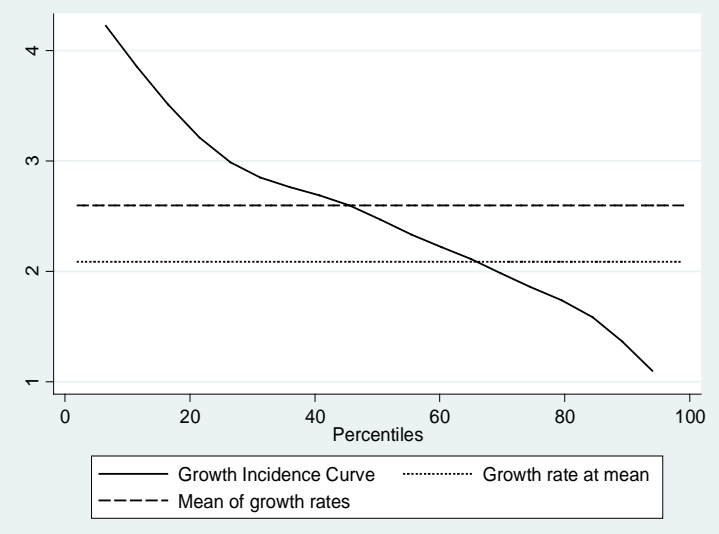

(c) $2001-2009$

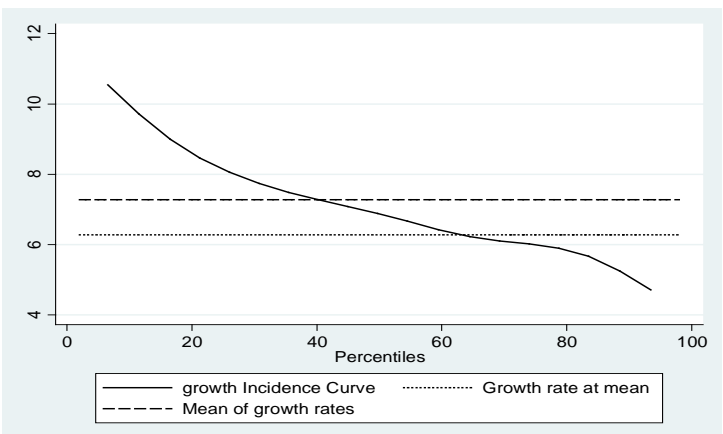

Source: Author's calculations from KHBS. (b) 2006-2009

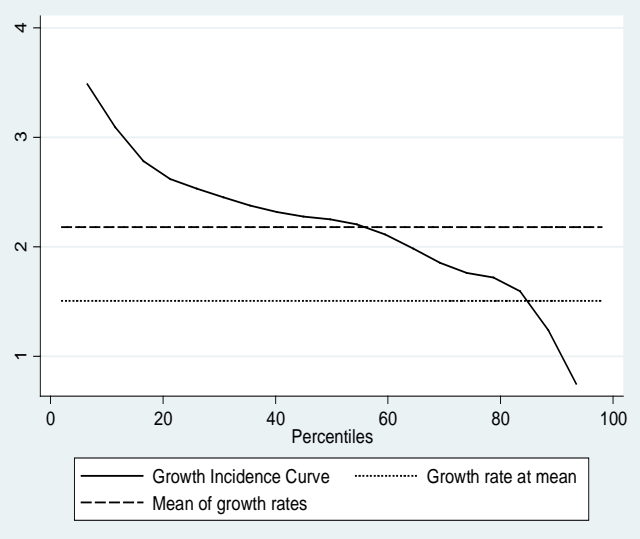

Looking at the GICs for the sub-periods 2001-2005 and 2006-2009 in Figures 1a and 1b, respectively, the shape of the GICs is very similar, with consumption growth of around 4 percent in each period for the lowest consumption percentiles, around 2.5 percent for the median, and around 1pecent for the highest consumption percentiles. The 2006-2009 GIC is slightly flatter than the 2001-2005 GIC, indicating that the crisis flattened consumption growth for the $20^{\text {th }}$ to $80^{\text {th }}$ percentiles compared to the earlier period.

In general, the GIC curves show a consistent pattern over the decade, with higher consumption growth for the groups at the bottom of the distribution and lower consumption growth for groups at the top of the distribution. In the second period, consumption growth appears to flatten out for the groups in the middle of the distribution, suggesting a more significant role for redistribution. We shall return to this issue below.

\section{Poverty equivalent growth rates}

Here we investigate the extent to which growth was pro-poor in Kazakhstan for the 20012009 decade, and the relative contributions of growth and redistribution to poverty 
reduction. Using cross-section data from the Kazakhstan Household Budget Survey, we estimate the poverty equivalent growth rate index proposed by Kakwani and Son. Table 1 summarises the main findings.

Table 1. Pro-poor growth in Kazakhstan

\begin{tabular}{|c|c|c|c|c|c|c|}
\hline \multicolumn{7}{|c|}{ (a) Pro-poor growth 2001-2005 } \\
\hline $\begin{array}{l}\text { Poverty } \\
\text { measure } \\
\text { (Baseline } \\
\text { 2001) }\end{array}$ & $\begin{array}{l}\text { Real } \\
\text { growth } \\
\text { rate }\end{array}$ & $\begin{array}{l}\text { Change } \\
\text { in } \\
\text { poverty } \\
\text { measure }\end{array}$ & $\begin{array}{l}\text { Poverty } \\
\text { growth } \\
\text { elasticity } \\
\text { (ठ) }\end{array}$ & $\begin{array}{l}\text { Relative } \\
\text { poverty } \\
\text { growth } \\
\text { elasticity } \\
\text { with } \\
\text { inequality } \\
\text { unchanged } \\
\text { (n) }\end{array}$ & $\begin{array}{l}\text { Relative } \\
\text { poverty } \\
\text { inequality } \\
\text { elasticity } \\
(\zeta)\end{array}$ & $\begin{array}{l}\text { PEGR } \\
\text { relative } \\
\left(\mathrm{Y}^{*}=\varphi \mathrm{Y}\right)\end{array}$ \\
\hline PO & 2.09 & -12.71 & -6.08 & -4.64 & -1.44 & 2.74 \\
\hline P1 & 2.09 & -6.34 & -3.03 & -1.89 & -1.15 & 3.36 \\
\hline $\mathrm{P} 2$ & 2.09 & -3.55 & -1.70 & -0.93 & -0.77 & 3.82 \\
\hline $\begin{array}{l}\text { Poverty } \\
\text { measure } \\
\text { (Baseline } \\
2006 \text { ) } \\
\end{array}$ & \multicolumn{6}{|c|}{ (b). Pro-poor growth 2006-2009 } \\
\hline PO & 1.50 & -11.12 & -7.41 & -4.05 & -3.36 & 2.74 \\
\hline P1 & 1.50 & -3.07 & -2.05 & -0.93 & -1.11 & 3.29 \\
\hline $\mathrm{P} 2$ & 1.50 & -1.19 & -0.79 & -0.31 & -0.49 & 3.79 \\
\hline $\begin{array}{l}\text { Poverty } \\
\text { measure } \\
\text { (Baseline } \\
\text { 2001) }\end{array}$ & \multicolumn{6}{|c|}{ (c). Pro-poor growth 2001-2009 } \\
\hline $\mathrm{PO}$ & 6.28 & -33.83 & -5.39 & -4.33 & -1.05 & 7.81 \\
\hline P1 & 6.28 & -12.83 & -2.04 & -1.43 & -0.62 & 9.00 \\
\hline P2 & 6.28 & -6.10 & -0.97 & -0.62 & -0.36 & 9.90 \\
\hline
\end{tabular}

Source: Author's calculations from KHBS.

Note: P0- Head-Count Ratio; P1- Poverty Gap; P2- Poverty Gap squared. The baseline poverty rates for 2001 are: $\mathrm{P} 0=46.7 ; \mathrm{P} 1=14.8 ; \mathrm{P} 2=3.5$. The baseline poverty rates for 2006 are: $\mathrm{P} 0=18.2 ; \mathrm{P} 1=7.5 ; \mathrm{P} 2=2.9$.

Beginning with the full period in Panel (c) of the Table, the reduction in the poverty headcount for the whole period is one-third, whereas the reduction in the poverty gap is 12.8 percent and the reduction in the poverty gap squared is 6.1 percent. The estimates of poverty growth elasticity are appropriately large: a 1 percent growth for the period 2001-2009 is associated with a 5.39 percent reduction in the poverty headcount rate; a 2 percent fall in the poverty gap and a 0.97 percent fall in the poverty gap squared. The high poverty growth elasticity for the poverty headcount rate is perhaps indicative of a large share of the population in poverty being located close to the poverty line, such that growth can be extremely effective in pulling them above the poverty line. Poverty growth 
elasticities are lower when the focus is on the poverty gap and the poverty gap squared, but they are still significant.

The next two columns provide information on the relative contributions of growth and redistribution (inequality reduction) on poverty. Taking the poverty headcount first, the main driver behind poverty reduction is growth, responsible for about four-fifths of the poverty reduction in the period. With an unchanged distribution of consumption, a 1 percent growth would have generated a 4.33 percent reduction in poverty. Redistribution contributes the remaining one-fifth. The contribution of redistribution rises when poverty gap measures are considered. Considering the poverty gap, redistribution is responsible for just below one-third of the reduction in poverty. When the poverty gap squared is considered, the contribution of redistribution is one-half of the reduction in poverty.

Turning to the estimates for the relative PEGR, the rate of growth that would have generated the same poverty reduction in the absence of changes in the distribution of consumption, it can observed that they are everywhere larger than the actual growth rate, suggesting a positive role for redistribution. The rates of growth needed to generate the same poverty reduction would have needed to be substantially higher in the absence of redistribution. The figures show that the difference between the PEGR and the actual growth rate rises when the poverty gap measures of poverty are considered. In the absence of redistribution, growth rates would have needed to be about one-third higher than they were, in order to achieve the same decline in the poverty gap and the poverty gap squared as it was observed. For the period 2001-2009, growth was relatively propoor in Kazakhstan, in the sense that poorer groups showed higher rates of consumption growth than the median or richer groups. The decline in poverty observed for the period reflects the combined effects of growth and redistribution. In the absence of redistribution, reducing consumption poverty among the poorest groups would have necessitated growth rates one-third higher.

When disaggregating by sub-period, 2001-2005 and 2006-2009, the figures in the Table show that the relative contribution of growth and redistribution changes between the two sub-periods. The contribution of redistribution becomes significantly larger in the 20062009 period, as can be seen from the decomposition of the poverty growth elasticity into its growth and inequality components. Considering the poverty headcount rate first, the growth component of the elasticity accounts for about four-fifths in the first period, but this falls to around three-fifths of the poverty elasticity in the second period. For the poverty gap measures, the dominance of the growth component in the first period is reversed in the second period, a trend which is even stronger for the poverty gap squared. As a consequence, the relative PEGR is over twice as large as the actual growth rate in the second period for the poverty gap and poverty gap squared poverty measures. Sustaining the reduction in poverty in the second period would have necessitated significantly higher rates of growth than those which materialised. This shows a stronger role for redistribution in the second period, and points to the role of 
redistributive policies associated with the stimulus in response to the financial crisis as a potential factor.

The main conclusion is that growth has been pro-poor in Kazakhstan over the period in question; but that redistribution becomes much more significant in sustaining poverty reduction in the second period. This finding is stronger when the focus is changes in consumption among the poorest. The next section focuses on this issue in more detail.

\section{Changes in households income and components}

This section examines changes in income sources for households in poverty in 2001, using a panel dataset for 2001-2009 constructed from cross-sections of the Kazakhstan Household Budget Survey. Identifying changes in the contribution of income sources will provide additional information on the relative significance of growth and redistribution in the rapid reduction of poverty in Kazakhstan for the 2001-2009 decade.

The findings from the last section point to a stronger growth effect in poverty reduction in the first half of the decade, followed by a stronger redistribution effect in the second half. The section begins by establishing the relative weight of income sources for households in poverty in 2001 over the decade. A confounding factor is that in Kazakhstan wage levels are strongly influenced by government. As a consequence, a rising contribution of labour earnings in household income and consumption could reflect rising demand and productivity in the economy or, alternatively, government wage policy. To investigate this issue, we first measure the relative contribution of the main sources of household income among poor households, and then estimate standard Mincer equations and an Oaxaca decomposition to distinguish between changes in endowments over time and changes in returns to these endowments. The findings from this analysis will throw light on the relative significance of redistribution channels in Kazakhstan.

\section{Changes in the relative weight of income components}

What are the main sources of the changes in household income among poor households over the decade? Table 2 illustrates the changes in the relative contribution of income sources to household income of households in poverty. The income sources reported in the survey were aggregated at the household level to distinguish the contribution of three main components: (i) market income, consisting of returns to household factors of production, labour and capital; (ii) state benefits, including the variety of direct benefits to households; and (iii) private transfers across households. These are computed for 2001, 2005 and 2009 for the households in poverty in the initial year. 
Table 2. Composition of total household income for poor households in 2001 and changes over time 2001-2009

\begin{tabular}{|c|c|c|c|}
\hline Sources of household income & 2001 & 2005 & 2009 \\
\hline Market income in total household income, including (\%): & 61.42 & 70.18 & 71.99 \\
\hline Labour earnings in total income $(\%)$ & 49.77 & 68.04 & 70.69 \\
\hline Share of capital earnings in total income (\%) & 11.66 & 2.14 & 1.30 \\
\hline State benefits in total household income (\%) & 31.95 & 21.51 & 23.23 \\
\hline Private transfers in total household income (\%) & 6.62 & 8.31 & 4.78 \\
\hline Total household income in real terms $(K Z T, 000 \mathrm{~s})^{\mathrm{a}}$ & 35.10 & 684.49 & 115.55 \\
\hline
\end{tabular}

Source: Author's calculations from KHBS.

${ }^{a}$ KZT-Kazakhstani Tenge, the national currency of Kazakhstan.

The main finding from the figures in the Table is that the share of market income in total household income increased during the period, while the share of state benefits and private transfers declined. The dominant factor in the rising share of market income is labour earnings. In fact, the share of earnings from capital in household income shows a marked decline between 2001 and 2005. Changes in the components of income are more significant in the 2001-2005 period than in the later period, except for the share of private transfers, which declined faster in the 2006-2009 period. The last row of Table 2 indicates the dynamics of real income for groups of households which are poor in 2001. The figures show close to a trebling of household income in the decade for households in poverty in 2001. In sum, the main driving force behind the significant improvement in the income of households in poverty in 2001 is the increase in labour earnings, in absolute terms and relative to the other sources of household income.

\section{Decomposition of changes in labour earnings}

To what extent are the changes in household income driven by changes in the demand for labour or by improvements in labour productivity, on the one hand; or by government wage policy, on the other? To investigate this issue we estimate Mincer equations for 2001 and 2009 for households in the panel and apply an Oaxaca (Oaxaca, 1973) decomposition. We focus on log per capita household income and on the differences between poor and non-poor households in 2001. The Oaxaca decomposition explains the poor/non-poor mean log household income gap. The gap is decomposed into that part due to group differences in endowments and that part due to differences in the returns to those endowments.

With $y_{i}$ the log of per capita household income, determined by a vector of endowments $x_{i}$, and two groups, poor and non-poor, a linear regression model is estimated separately on each of the two groups as:

$$
y_{i}=\left\{\begin{array}{l}
\beta^{\text {poor }} x_{i}+\varepsilon_{i}^{\text {poor }} \text { if poor } \\
\beta^{\text {nonpoor }} x_{i}+\varepsilon_{i}^{\text {nonpoor }} \text { if nonpoor }
\end{array}\right.
$$


The difference in outcomes can be expressed in either of two ways:

$y^{\text {nonpoor }}-y^{\text {poor }}=\Delta x \beta^{\text {poor }}+\Delta \beta x^{\text {nonpoor }}$

where $\Delta x=x^{\text {nonpoor }}-x^{\text {poor }}$ and $\Delta \beta=\beta^{\text {nonpoor }}-\beta^{\text {poor }}$, or as:

$y^{\text {nonpoor }}-y^{\text {poor }}=\Delta x \beta^{\text {nonpoor }}+\Delta \beta x^{\text {poor }}$

The decompositions in equations (9) and (10) are a special case of more general decomposition:

$y^{\text {nonpoor }}-y^{\text {poor }}=\Delta x \beta^{\text {poor }}+\Delta \beta x^{\text {poor }}+\Delta x \Delta \beta=E+C+C E$

Therefore, the gap in mean outcomes can be decomposed into a gap in endowments $(E)$, a gap in coefficients (C), and a gap arising from the interaction of endowments and coefficients (CE).

With the panel data it will be possible to decompose the changes over time for the 2001 poor group only, comparing the group which remained poor and the group which escaped from in 2009. The following equation describes this decomposition for 2001 poor group only:

$$
\Delta y=\left\{\begin{array}{l}
\beta^{\text {poor }} x_{i}+\varepsilon_{i}^{\text {poor }} \text { if poor in } 2001 \text { and poor in } 2009 \\
\beta^{\text {nonpoor }} x_{i}+\varepsilon_{i}^{\text {nonpoor }} \text { if poor in } 2001 \text { and nonpoor in } 2009
\end{array}\right.
$$

$\Delta y^{\text {nonpoor }}-\Delta y^{\text {poor }}=E+C+C E, \Delta \mathrm{y}$ is the change of income between 2009 and 2001.

Table 3 presents the results of Oaxaca decomposition for panel data for 2001 and 2009. ${ }^{6}$

The first column shows the results from a decomposition of the log per capita household income gap observed between poor and non-poor households in 2001. The vector of characteristics includes: head of household characteristics, such as gender, marital status, ethnicity, education level and employment status; demographic structure of

\footnotetext{
${ }^{6}$ The description of variables and estimation results can be found in Appendix 1 . The main determinants of the earnings gap between poor and non-poor households in 2001 are assets, location in the south, number of children, and number of working-age women. For 2009, the main determinants are household size, assets, education of the head of household. However, for those groups of households which are poor in 2001, the main determinants of change in the household income gap between households which managed to escape poverty in 2009 and those which remained poor are ethnicity, whether head of household is a pensioner; whether employed in public sector, household size and assets.
} 
Table 3. Oaxaca decomposition of determinants of the gap in log per capita household income between poor and non-poor groups for 2001 and 2009 (standard errors in brackets)

\begin{tabular}{|c|c|c|c|}
\hline & \multicolumn{2}{|l|}{ Full sample } & \multirow{2}{*}{$\begin{array}{l}\text { Sample of households } \\
\text { poor in } 2001 \\
\text { Poor and non-poor in } \\
2009\end{array}$} \\
\hline & $\begin{array}{l}\text { Poor and non- } \\
\text { poor in } 2001\end{array}$ & $\begin{array}{l}\text { Poor and non- } \\
\text { poor in } 2009\end{array}$ & \\
\hline & 2001 & 2009 & 2009- \\
\hline Predicted mean non-poor & $\begin{array}{l}9.099 \\
(0.01)\end{array}$ & $\begin{array}{r}10.11 \\
(0.012)\end{array}$ & $\begin{array}{r}9.874 \\
(0.012)\end{array}$ \\
\hline Predicted mean poor & $\begin{array}{l}8.116 \\
(0.01)\end{array}$ & $\begin{array}{r}9.716 \\
(0.013)\end{array}$ & $\begin{array}{r}9.140 \\
(0.013)\end{array}$ \\
\hline Difference & $\begin{array}{r}0.982 \\
(0.014)\end{array}$ & $\begin{array}{r}0.399 \\
(0.017)\end{array}$ & $\begin{array}{r}0.733 \\
(0.028)\end{array}$ \\
\hline Decomposition: & & & \\
\hline due to endowments (E) & $\begin{array}{r}0.238 \\
(0.012)\end{array}$ & $\begin{array}{r}0.245 \\
(0.015)\end{array}$ & $\begin{array}{r}0.218 \\
(0.022)\end{array}$ \\
\hline due to coefficients ( C ) & $\begin{array}{l}0.667 \\
(0.02)\end{array}$ & $\begin{array}{r}0.086 \\
(0.018)\end{array}$ & $\begin{array}{r}0.461 \\
(0.032)\end{array}$ \\
\hline due to interaction (CE) & $\begin{array}{r}0.085 \\
(0.019)\end{array}$ & $\begin{array}{r}0.067 \\
(0.016)\end{array}$ & $\begin{array}{l}0.091 \\
(0.03)\end{array}$ \\
\hline
\end{tabular}

Source: Author's calculations.

household: number of children, number of working age men and women, number of nonworking age men and women; and household location and assets. Two-thirds of the poor/non-poor earnings gap in 2001 is explained by differences in the coefficients, and a quarter of the gap is explained by differences in endowments.

The second column performs the same decomposition for the logarithm of per capita household income of 2009 and household characteristics in 2009. The figures show a significant reduction in the earnings gap between poor and non-poor groups, to around 40 percent of the measured gap in 2001. The shares of the gap explained by endowments and the interaction term remain similar to those in 2001, but the share of the earnings gap explained by the returns to the endowments falls sharply to around one-fifth of the gap in 2009. This implies that the reduction in the earnings gap between poor and non-poor households between 2001 and 2009 is largely explained by changes in the returns to endowments. In the context of Kazakhstan, the results point to the role of government wage policy in sustaining a rise in wages and salaries, especially as slower growth in the second part of the decade would be consistent with weaker demand in the labour market. 
The third column of Table 3 explains the difference in earnings for 2001 and 2009 between poor and non-poor households in 2009, but taking only households observed to be in poverty in 2001. It compares the households which managed to escape poverty in 2009 with the households remaining in poverty. The household income gap is large, and it is mainly explained by changes in the returns to endowments. This result again proves that for those which escaped poverty in 2009 , the main role is played by government policy.

\section{Conclusion}

The paper examined the contribution of growth and redistribution in explaining the rapid reduction in poverty in Kazakhstan in the 2001-2009 decade. The poverty headcount rate declined by 33 percent in the decade, with smaller reductions in the poverty gap (12 percent) and the poverty gap squared (6 percent). Most importantly, the reduction in poverty has been sustained through the 2007 global financial crisis. Rising production and prices of oil generated the conditions for sustained growth in the economy in the earlier part of the decade, but growth slowed down towards the end of the decade. The government responded to the crisis with a large stimulus package financed from oil revenues. The stimulus package reinforced the impact of antipoverty programmes in place since the beginning of the decade whilst broadening public support to cover a large section of the population. Wage rises and increases in the level of pensions and state benefits have been important too.

The paper considers the relative role of growth and redistribution in sustaining poverty reduction, based on an analysis of household survey data from the Kazakhstan Household Budget Survey. The main findings are as follows:

Growth incidence curves of household per capita consumption illustrate the fact that consumption growth has been relatively prop-poor, insofar as the rates of growth in consumption experienced by groups at the bottom of the distribution of household consumption are significantly higher than the rates of consumption growth in the middle of the distribution and at the top. The GICs for the whole period and for two sub-periods, 2001-2005 and 2006-2009, show a consistent pattern. They are positive and strictly decreasing over all percentiles, implying that poverty and inequality have declined during the decade.

The paper then reported on estimates of a pro-poor growth index, the poverty equivalent growth rate. We found that growth was relatively pro-poor for the period as a whole and for each of the sub-periods. A decomposition of the poverty reduction elasticities shows that growth was the main driver behind poverty reduction in the 2001-2009 period, but redistribution became more important in the 2006-2009 period. The estimated relative PEGRs indicate that, in the absence of redistribution, rates of growth would have needed to be significantly higher to generate the observed reduction in poverty. This applies particularly to poverty growth elasticities associated with poverty gap measures. 
Growth appears to have been more successful in lifting those households close to the poverty line above it, but redistribution has been more successful in reducing the poverty gap among the poorest.

What are the main channels through which growth and redistribution improve the welfare of groups in poverty? An analysis of changes in the share of the different components of household income for households in poverty in 2001 shows that the share of labour earnings increased in absolute and in relative terms over the whole period, but especially in the 2001-2005 period. The share of state benefits in household income declined in the first sub-period, but increased marginally during the second sub-period. To what extent do the changes in labour earnings reflect labour market conditions or government wage policy? An Oaxaca decomposition of log per capita household income identified the contribution of endowments and returns to endowments in explaining changes in the gap between per capita household income across households in poverty and those not in poverty in 2001; and across households in poverty in 2001 which exited poverty and those that remained in poverty in 2009. The earnings gap between poor and non-poor households declines significantly between 2001 and 2009, but the contribution of endowments to explaining this gap remains stable. The main contribution to the reduction in the gap comes from changes in the return to these endowments, which benefit households in poverty. The returns to endowments also explain the large share of the gap in log household income existing between households in poverty in 2001 which exit poverty and those that remain in poverty. These results suggest that government wage policy is likely to have been a key driver in sustaining the decline in poverty in the second half of the decade.

In conclusion, the rapid reduction in poverty in Kazakhstan is explained primarily by growth in the first half of the decade, and by redistribution in the second half of the decade. Growth has been pro-poor in Kazakhstan over the 2001-2009 period, but redistribution gained in significance in the second half, especially through the effects of the stimulus package and public policy, leading to significant wage rises. The sharp decline in the poverty headcount rate in Kazakhstan in the first decade of the new century is a significant achievement. It reflects the combine effects of growth and redistribution. Sustaining this rate of poverty reduction over the next decade will require finding an appropriate balance between growth and redistribution. 


\section{References}

Agrawal, P. (2008). 'Economic growth and poverty reduction: evidence from Kazakhstan'. Asian Development Review, 24(2), 90-115.

Deaton, A. and Paxson, C. (1998). 'Economies of scale, household size, and the demand for food'. Journal of Political Economy, 106(5), 897-930.

Deaton, A. S. and Muellbauer, J. (1986). 'On measuring child costs: with applications to poor countries'. Journal of Political Economy, 94(4), 720-744.

Foster Greer, J. and Thorbecke, E. J. (1984). 'A class of decomposable poverty measures'. Econometrica, 52(3), 761-769.

Hare Naumov, A. P. (2008). 'A study of changing income distribution in Kazakhstan using a new social accounting matrix and household survey data'. In 30th General Conference of the International Association for Research in Income and Wealth. .

Jandosov Sabyrova, L. and Mogilevsky, R. O. (2010). 'Fiscal anti-crisis package by the Government of Kazakhstan in 2009. Part 2: How effective?' Discussion Papers, Rakurs Center for Economic Analysis, 5.2.

Kakwani, N. and Pernia, E. M. (2000). 'What is pro-poor growth?' Asian Development Review, 18(1), 1-16.

Kakwani, N. and Son, H. H. (2008). 'Poverty equivalent growth rate'. Review of Income and Wealth, 54(4), 643-655. 
Lanjouw, P. and Ravallion, M. (1995). 'Poverty and household size'. The Economic Journal, 105(433), 1415-1434.

Oaxaca, R. (1973). 'Male-female wage differentials in urban labor markets'. International Economic Review, 14(3), 693-709.

Pomfret, R. (2005). 'Kazakhstan's economy since independence: does the oil boom offer a second chance for sustainable development?' Europe-Asia Studies, 57(6), 859-876.

Ravallion, M. and Chen, S. (2003). 'Measuring pro-poor growth'. Economics Letters, 78(1), 93-99.

UNDP Kazakhstan. (2008). Poverty in Kazakhstan: Causes and Cures.

Verme, P. (2006). 'Pro-poor growth during exceptional growth. Evidence from a transition economy'. The European Journal of Comparative Economics , 3(1), 314. 


\section{Description of variables}

\begin{tabular}{|l|l|}
\hline $\begin{array}{l}\text { Variable } \\
\text { name }\end{array}$ & Definition \\
\hline agehh & Age of head of household \\
\hline vochh & Head of household has vocational education \\
\hline highh & Head of household has higher education \\
\hline sechh & Head of household has secondary education \\
\hline kazakh & Ethnicity of head of household is kazakh \\
\hline marriedhh & Head of household is married \\
\hline genderhh & Gender of the head of household is male \\
\hline unemp & Head of household is unemployed \\
\hline public & $\begin{array}{l}\text { Head of household is employed in public } \\
\text { sector }\end{array}$ \\
\hline selfempl & Head of household is self-employed \\
\hline private & $\begin{array}{l}\text { Head of household is employed in private } \\
\text { sector }\end{array}$ \\
\hline pens & Head of household is pensioner \\
\hline hhsize & Household size \\
\hline ch_6 & Number of children under six in household \\
\hline ch7_14 & $\begin{array}{l}\text { Number of children between seven and 14 in } \\
\text { household }\end{array}$ \\
\hline w_agem & Number of working age men \\
\hline w_agew & Number of working age women \\
\hline nw_agem & Number of non-working age men \\
\hline nw_agew & Number of non-working age women \\
\hline central & $\begin{array}{l}\text { Household is located in Central part of } \\
\text { Kazakhstan }\end{array}$ \\
\hline west & $\begin{array}{l}\text { Household is located in Western part of } \\
\text { Kazakhstan }\end{array}$ \\
\hline north & $\begin{array}{l}\text { Household is located in Northern part of } \\
\text { Kazakhstan }\end{array}$ \\
\hline south & $\begin{array}{l}\text { Household is located in Southern part of } \\
\text { Kazakhstan }\end{array}$ \\
\hline east & $\begin{array}{l}\text { Household is located in Eastern part of } \\
\text { Kazakhstan }\end{array}$ \\
\hline rural & Household is located in rural area \\
\hline logasset & Logarithm of household's assets \\
\hline
\end{tabular}


(a) Results from implementing an Oaxaca decomposition of the determinants of the gap in log per capita household income between poor and non-poor groups for 2001 and 2009 (Z statistics in brackets)

\begin{tabular}{|c|c|c|c|c|c|c|}
\hline \multirow[b]{3}{*}{ Variables } & \multicolumn{4}{|c|}{ Full sample } & \multirow{2}{*}{\multicolumn{2}{|c|}{$\begin{array}{c}\begin{array}{c}\text { Sample of households poor in } \\
2001\end{array} \\
2009 \\
\end{array}$}} \\
\hline & \multicolumn{2}{|c|}{2001} & \multicolumn{2}{|c|}{2009} & & \\
\hline & Endowments & Coefficients & Endowments & Coefficients & Endowments & Coefficients \\
\hline agehh & $0.001(0.49)$ & $0.038(0.56)$ & $0.013^{* \star *}(3.11)$ & $\begin{array}{l}-0.224^{\text {Nkx }}(- \\
2.72)\end{array}$ & $0.000(0.08)$ & $0.144(0.97)$ \\
\hline vochh & $0.001(1.18)$ & $0.006(0.48)$ & $-0.0001(-0.09)$ & $-0.004(-0.2)$ & $0.001(0.39)$ & $0.014(0.32)$ \\
\hline highh & $0.007(1.36)$ & $0.006(1.39)$ & $0.019^{\star \star \star}(2.9)$ & $0.004(0.57)$ & $0.005(0.34)$ & $0.003(0.48)$ \\
\hline sechh & $-0.005(-1.28)$ & $-0.009(-0.62)$ & $-0.006(-1.01)$ & $-0.017(-0.9)$ & $0.004(0.31)$ & $0.039(0.8)$ \\
\hline kazakh & $-0.004(-1.06)$ & $0.002(0.13)$ & $-0.019^{\star * \star}(-2.7)$ & $-0.015(-0.74)$ & $\begin{array}{r}-0.024^{* *}(- \\
2.25) \\
\end{array}$ & $-0.106^{\star *}(-2.12)$ \\
\hline marriedhh & $-0.003(-1.11)$ & $-0.056^{\star *}(-2.06)$ & $-0.001(-0.9)$ & $-0.006(-0.42)$ & $0.003(0.75)$ & $-0.033(-1.33)$ \\
\hline genderhh & $0.002(0.47)$ & $0.033(1.59)$ & $0.001(0.39)$ & $-0.007(-0.48)$ & $-0.000(-0.12)$ & $-0.025(-0.94)$ \\
\hline unemp & $-0.0002(-0.31)$ & $-0.003(-0.93)$ & $0.002^{*}(1.7)$ & $-0.001(-0.29)$ & $0.001(0.51)$ & $-0.003(-0.47)$ \\
\hline public & $-0.0004(-0.47)$ & $0.006(0.95)$ & $-0.0004(-0.25)$ & $0.004((0.51)$ & $0.005^{*}(1.49)$ & $0.007(0.61)$ \\
\hline selfempl & $0.001(1.2)$ & $0.000(0.06)$ & $-0.001(-1.13)$ & $\begin{array}{l}-0.0004(- \\
0.14)\end{array}$ & $0.000(0.37)$ & $0.008(1.1)$ \\
\hline private & $0.005^{\star \star}(2.59)$ & $-0.011^{* \star}(-2.4)$ & $0.003(1.52)$ & $0.008(1.08)$ & $-0.001(-0.28)$ & $0.007(0.65)$ \\
\hline pens & $0.002(0.73)$ & $-0.009(-1.18)$ & $0.006(1.08)$ & $0.0001(0.02)$ & $0.003^{*}(1.81)$ & $-0.002(-0.23)$ \\
\hline hhsize2001 & $0.019^{\star *}(1.88)$ & $0.026(0.54)$ & $0.178^{\star \star \star}(13.79)$ & $-0.037(-0.79)$ & $0.116^{\star \star *}(3.05)$ & $\begin{array}{r}-0.324^{* \pi \times}( \\
2.76) \\
\end{array}$ \\
\hline ch_6 & $0.021^{\star \star \star}(4.69)$ & $-0.032^{* \star}(-2.43)$ & $0.003(1.59)$ & $0.001(0.17)$ & $0.003(0.32)$ & $-0.000(0.01)$ \\
\hline ch7_14 & $0.054^{\star \star \star}(7.87)$ & $\begin{array}{l}-0.057^{\text {*x* }}(- \\
3.01)\end{array}$ & $0.007^{* \star}(2.23)$ & $-0.002(-0.19)$ & $-0.008-0.61)$ & $-0.033(-1.25)$ \\
\hline w_agem & $0.014^{* * \star}(2.67)$ & $\begin{array}{l}-0.088^{* \pi \times}(- \\
3.69)\end{array}$ & $-0.002(-0.31)$ & $0.024(0.98)$ & $-0.000(-0.03)$ & $0.014(0.3)$ \\
\hline w_agew & $0.022^{\star \star \star}(3.83)$ & $0.018(0.64)$ & $0.000(0.02)$ & $0.004(0.24)$ & $0.004(0.42)$ & $-0.005(-0.18)$ \\
\hline
\end{tabular}




\begin{tabular}{|c|c|c|c|c|c|c|}
\hline nw_agem & $0.001(0.82)$ & $\begin{array}{l}-0.015^{* * *}(- \\
3.45)\end{array}$ & $0.0010(0.38)$ & $0.004(0.98)$ & $0.000(0.000)$ & $0.001(0.14)$ \\
\hline nw_agew & $-0.0003(-0.15)$ & $-0.019^{* *}(-2.18)$ & $-0.003(-0.25)$ & $0.009(1.25)$ & $0.016(1.09)$ & $-0.006(-1.02)$ \\
\hline central & $0.003(1.69)$ & $\begin{array}{l}-0.024^{\text {र*x }}(- \\
3.46)\end{array}$ & $-0.002(-1.05)$ & $-0.003(-0.36)$ & $-0.001(-0.2)$ & $-0.010(-0.85)$ \\
\hline west & $0.001(0.81)$ & $\begin{array}{l}-0.017^{* \pi k}(- \\
2.67)\end{array}$ & $-0.000(-0.00)$ & $\begin{array}{l}-0.008^{*}(- \\
1.69)\end{array}$ & $0.000(-0.1)$ & $-0.003(-0.27)$ \\
\hline north & $-0.002(-0.77)$ & $-0.015^{* *}(-2.48)$ & $-0.007^{\star *}(-2.4)$ & $0.005(0.71)$ & $-0.001(-0.43)$ & $-0.010(-0.75)$ \\
\hline south & $0.019^{\star \star \star}(3.57)$ & $\begin{array}{l}-0.069^{\text {xik }}(- \\
4.99)\end{array}$ & $0.015^{* * \star}(2.85)$ & $-0.046^{* * *}(-3.4)$ & $-0.001(-0.26)$ & $-0.052(-1.84)$ \\
\hline east & $0.001(0.52)$ & $-0.015^{\star \star \star}(-2.9)$ & $-0.001(-0.55)$ & $-0.008(-1.4)$ & $-0.015(-0.74)$ & $0.010(1.29)$ \\
\hline rural & $0.002(0.30)$ & $-0.006(-0.32)$ & $0.009(1.29)$ & $-0.005(-0.25)$ & $\begin{array}{r}-0.007^{*}(- \\
1.65) \\
\end{array}$ & $-0.074(-1.38)$ \\
\hline logasset & $0.066^{\star \star \star}(8.89)$ & $-0.022(-0.19)$ & $0.029^{\star \star \star}(5.27)$ & $0.156(0.93)$ & $0.017^{\star \star \star}(2.89)$ & $0.422(1.35)$ \\
\hline Total & $0.229^{\star \star \star}(17.89)$ & $0.668^{\star \star \star}(32.98)$ & $0.245^{* \star \star}(16.27)$ & $0.087^{\star \star \star}(4.73)$ & $0.119^{\star \star \star}(2.77)$ & $0.648^{\star \star \star}(18.03)$ \\
\hline Constant & & $0.999^{\star \star \star}(6.72)$ & & $0.248(1.16)$ & & $0.666^{*}(1.78)$ \\
\hline $\operatorname{AdjR}^{2}$ & \multicolumn{2}{|c|}{0.47} & \multicolumn{2}{|c|}{0.45} & & 0.36 \\
\hline
\end{tabular}

Note: Omitted categories: for location is Almaty-Astana (two biggest cities), for demographic variables are age between 14 and 17 . z-statistics in parentheses. ${ }^{*} p<0.10,{ }^{* *} p<0.05,{ }^{* * *} p<0.01$

Source: Author's estimations from KHBS. 


\section{MANCHESTER 1824}

The University of Manchester

Brooks World Poverty Institute

\section{Executive Director}

Professor David Hulme

\section{Research Directors}

Professor Armando Barrientos

Professor Rorden Wilkinson

\section{Contact:}

\section{Brooks World Poverty Institute}

The University of Manchester

Arthur Lewis Building

Oxford Road

Manchester

M13 9PL

United Kingdom

\section{Email: bwpi@manchester.ac.uk}

The Brooks World Poverty Institute (BWPI) creates and shares knowledge to help end global poverty.

BWPI is multidisciplinary, researching poverty in both the rich and poor worlds.

Our aim is to better understand why people are poor, what keeps them trapped in poverty and how they can be helped - drawing upon the very best international practice in research and policy making. 